\title{
BIG FM 92.7 AND KFCC: A CASE OF CONFLICT RESOLUTION THROUGH MEDIATION
}

\author{
${ }^{1}$ Ms. Seema Sambargi, $\quad{ }^{2}$ Ms. Asha Ganesh
}

\begin{abstract}
This case study details how perceptual and cultural differences lead to a conflict between a corporate house and the Kannada film industry. It also shows how the choice of mediator who can empathise with both sides can resolve conflicts.
\end{abstract}

Key words: Sandalwood, KFCC, Big FM 92.7, conflict resolution, empathise, balance of power, appease, mediation, pride.

\section{Protagonists:}

Big FM 92.7: The radio arm of Reliance Broadcast Network Limited (earlier known as Reliance Media World Ltd.)

KFCC: Karnataka Film Camber of Commerce, an association of stakeholders in the Kannada Film Industry

\section{Back ground:}

It all began on $16^{\text {th }}$ July 2010 , when Radio Jockey (RJ) Rock star Rohit while hosting a program 'Sakkath Chathri' on 92.7 BIG FM , a popular radio music station in Bangalore, asked the audience a question-"Who is the biggest Chathri in Sandalwood?". The, word 'chathri' in Kannada slang means fraudster. Members of the audience across Bangalore called in the music station to express their views and opinions, which were being broadcast live. Many views and opinions were expressed, and allegedly the Radio Jockey during the course of his conversations, instigated the audience to say negative things about the Kannada film industry in general and film directors in particular. Caustic remarks about the 'casting couch' were aired, without explicitly naming any director, but the audience was given enough hints to implicate prominent directors.

Many prominent members of the industry took offence to this and brought it to the notice of Karnataka Film Chamber of Commerce (KFCC). An Executive Committee meeting was called by KFCC on $17^{\text {th }}$ July to discuss the same. It was decided in the meeting to issue a 'SHOW CAUSE NOTICE' to the $\mathrm{RJ}$ and the radio station, seeking an explanation. The notice also sought an apology and a reply in person, by the RJ. The aforesaid notice dated $18^{\text {th }}$ July 2010, and the subsequent one dated the next day, were left un heeded and unacknowledged by the Radio station. This agitated the members of the film fraternity. So, on $21^{\text {st }}$ July, a select few members affiliated to KFCC led by Mr M S Ramesh, President of Directors' Association barged into Big FM office ,created a scene and demanded the RJ to appear before the KFCC.

1 Ms. Seema Sambargi, Asst. Professor, MBA Department, S R N ADARSH COLLEGE Bangalore

She can be reached at seemasambargi@gmail.com

2 Ms. Asha Ganesh Principal, C B Bhandari Jain College, Bangalore.

She can be reached at ashaganesh29@yahoo.co.in 


\section{Initial Negotiations}

The Producer and the Script writer of the show Mr. Harsha and RJ Rohith, with their legal counsel, met the KFCC members on $22^{\text {nd }}$ at the Chamber office. The KFCC contingent was led by its President Mr Basanth Kumar Patil and Vice President K Manju. In this meeting, the Big FM team pleaded guilty and apologized. But, they tried to rationalize their action citing 'creative expression and freedom' reasons and RJ Rohith stood by his remarks on casting couch ,which KFCC found judgmental and objectionable. During the course of discussion, the RJ tried to defend himself by saying that he had performed according to the script, and that script was not his. With the onus on him now to explain, Producer Harsha was at a loss for words. During his defense, he gave an impression to KFCC that it was his management which mandated him to come up with scintillating programmes. This led to the creation of a perception in the minds of KFCC members that, the company policy of Big FM and hence Reliance was anti local art and culture. This stance of the Big $F M$ irritated and agitated the members of KFCC.KFCC was not convinced with the explanation and hence refused to accept their apology. KFCC asked the Big FM team to send in person some Company official, higher up in the hierarchy to explain this 'anti Kannada policy'.

KFCC called its General Body meeting on the $23^{\text {rd }}$ July. Emotions were running high and every member who spoke, pointed out to the controversies and skirmishes Reliance seemed to be having, with the Kannada film industry. Controversies regarding the release of 'Raavan' and 'Kites' (both big budget Hindi Movies distributed by Reliance Big Movies) were cited. People at KFCC were smarting from the fact that the Competition Council of India, acting on a complaint from Reliance Big Movies had over ruled KFCC and permitted Reliance Big Movies to screen Raavan in more than 24 screens. And now, the 'Chathri programme' seemed to have added injury to insult. It was decided in this meeting, that the onus of explaining the stand of Reliance in this matter, would be on Mr. Sunil Kumaran, Cluster head of Big
FM from Karnataka and Kerala. He was to come in person to the Chamber office and explain.

\section{Talks Fail-Bundh Announced}

When Mr Kumaran, met the KFCC office bearers and members on the $29^{\text {th }}$ July, he was asked a series of questions on the perceived anti Kannada Film industry policy of Reliance. Mr Kumaran was of the opinion that KFCC was making a mountain out of a mole hill and it was not a policy matter of the Reliance group to be anti Kannada. He offered monetary compensation to appease the agitated KFCC. This attitude further hurt the sentiments of KFCC, which cried hoarse, that its honor was not for sale. Clearly, there was a cultural mismatch between the representative of Reliance and KFCC. Since Mr Kumar was neither a local nor seemed to know the nuances of Sandalwood, there seemed to be communication gap and he was perceived by KFCC to be arrogant and insensitive to the issue.

On the $30^{\text {th }}$ July, the office bearers of KFCC summoned RJ Rohith, producer Harsha and the Station Head Mr Kumar to their office and presented to them the following demands.

+ RJ Rohith and producer Harsha to be sacked.

$+\quad$ One month shutdown of the radio station.

KFCC also made it clear as to what would happen if Big FM did not meet its demand by $31^{\text {st }}$ July.

$+\quad$ No actor from Sandalwood would be associated with any of Big FM programmes.

$+\quad$ No Kannada movie advertisements on Big FM.

+ Sandalwood would boycott all awards by Big FM.

+ RJ Rohith and producer Harsha would be boycotted even if they are associated with other channels.

Mr Kumar presented himself in the Chamber office on the morning of $31^{\text {st }}$ July in the full attendance of KFCC members. The Station Master acceded to the 
suspension of RJ for one month and tendering a written apology, but would not budge beyond this. KFCC was adamant that its demands be met and was not at all satisfied with the accessions made by Big FM. This led to further heated discussions among the members of KFCC who then decided to call for a Kannada film industry bundh on Monday, the 2nd August 2010. A protest march was also planned from Vidhana Soudha to office of 92.7 Big FM radio station in Koramangala, Bangalore. KFCC called for a press meet at $4 \mathrm{pm}$ the same day, to announce the Bundh and the protest march to the press \& the public.

The office bearers of KFCC met the Police Commissioner, to seek permission for the bundh and to get the route of the protest march sanctioned. Since all the prominent stars of Sandalwood were expected to join the protest march, the situation could potentially turn into a law and order problem. The Commissioner in his official capacity, had tried to set up a negotiation meeting between KFCC and the Special Officer of Reliance ADAG and Karnataka Circle Group Coordinator, Mr.S.Narasimhan. But even before $\mathrm{Mr}$ Narasimhan reached the Commissioner's office, KFCC brought high political pressure on the Commissioners office and by $6: 00$ pm succeeded in getting permission for the bundh and the protest march.

As a protocol, this information was passed on to Information Minister Mr.Katta Subramanya Naidu who also overlooks the matters relating to the film industry This became breaking news and was flashed across TV screens

It was at this juncture that Mediator Mr Prashanth Sambargi entered the picture

If the bundh and protest march were held as per KFCC plans, a lot was at stake for Reliance. Its brand image would take a beating; it would lose good will among Kannadigas, its assets and property, and the lives of its radio station employees were in danger if the crowd were to go out of control. Reliance sent a request letter to the police department for protection.

At this juncture Mr.Tarun Katiar ,CEO BIG Radio,
Mumbai called Mr. Prashanth Sambargi asking him to intervene. Mr. Katiar had met Mr Sambargi during the launch of 92.7 Big FM Radio in October 2006. Mr Sambargi was the Event and Celebrity Manager for that particular event. Also, he was a Reliance Web World franchisee. It should at this point be noted that Mr Sambargi was instrumental in making the Sandalwood star Mr Upendra, the Brand Ambassador of 92.7Big FM Radio, Bangalore. This was unprecedented as until then, no radio channel had a movie star as its brand ambassador.

When Mr Prashanth asked for a day's time to gather information and revert, Mr Katiar categorically stated that the issue was to be resolved immediately. Meanwhile Mr Prashanth came to know through his sources in the media that, KFCC had released half page advertisements in all leading Kannada dailies, that the expected turn out for the protest march could between five and ten thousand people, and that the office bearers were contacting all top hero and heroines to attend the march. This made the intent of KFCC loud and clear.

Mr Prashanth called back Mr Katiar to report to him all the information he had gathered.

Mr. Katiar requested Mr Prashanth to resolve the issue. He asked Mr Prashanth to try and withdraw the ads on priority and also to try and negotiate to satisfy KFCC demands. He was authorized to agree to anything and everything (including monetary, ad spots, and special programmes) other than closure of radio station.

By 7:00 pm Mr. Prashanth made a call to Mr Rockline Venkatesh, an executive member of KFCC, requesting for a meeting. He was harshly declined because he could not convince Mr Venkatesh that he was vested with the authority to negotiate the KFCC demands on behalf of Reliance.

Mr Prashanth then arranged for a fax to be sent to the Chamber which gave him the status of single point of contact from Reliance with all authority to negotiate with KFCC.

He then called Mr K Manju, another executive 
member of KFCC, requesting for a meeting and assures KFCC of fulfilling its wish list. Mr Prashanth was asked to come to the Chamber office, but he declined and chose a neutral place instead -the Taj West End hotel.

By 7:45 Mr Prashanth along with Mr. Narasimhan and Mr. Sunil Kumaran reached West End expecting to meet two or three KFCC office bearers. But, he was surprised to find more than 30 people, all connected with Sandalwood, waiting near the Coffee Shop which was the intended meeting place.

Since the hotel authorities were not able to arrange for a meeting hall for such a big gathering at such a short notice, the meeting venue was shifted back to Chamber office.

Meanwhile, Mr Prashanth had conveyed to the KFCC office bearers, to freeze on a full and final wish list of demands, that Reliance was supposed to fulfill.

It was $8: 00 \mathrm{pm}$ by the time meeting finally began in the Chamber with now more than a 100 members having gathered. Mr Prashanth began the talks by introducing himself and laying emphasis on the fact that he too was part of Sandalwood by virtue of being marketing manager and financer for many Kannada movies, media consultant for many production houses and celebrity manager for Sandalwood stars. Thus having established himself as a stakeholder of Sandalwood, he offered an olive branch on behalf of Reliance.

At this point, Mr Basanth Kumar Patil, the President of KFCC asked Mr. Prashanth if he had listened to the audio clipping containing the RJ's comments which started this controversy in the first place. When $\mathrm{Mr}$ Prashanth answered in the negative, arrangements were made for the audio clipping to be played immediately. When Mr. Prashanth listened to the clipping, he immediately empathized with KFCC and said that the perpetrators of the disgusting act deserved to be punished. Sensing that Prashanth had conceded them a point and that they had a positive balance of power, members of KPCC continued to insist, that the radio station close down for a month.

At this point, Mr Prashanth asked the members of KFCC what they would gain by getting Big FM to close down for a month. Instead, he suggested, by keeping it open and Big FM airing its apology every half an hour, KFCC stood to gain better. He also went on to explain as to why it was not possible to close down the station. He said that there was no precedence of any radio station shutting down for reasons, other than war or natural calamities. He proposed a written apology to KFCC from Big FM and airing of apology every half hour; and if KFCC insisted, suspension of the RJ and no more than that, and certainly no closure of the radio station, as it was bad for the image of Reliance, a public listed company. He also offered ad spots and special programs for the promotional activities of Sandalwood.

Members of KFCC, at this point, commented that it was not their concern as to what was good or deterimental for the image of a company whose policies were anti Kannada. Mr. Prashanth defended Reliance and convinced the members of KFCC that Reliance was not anti Kannada by pointing out to the following facts

$+\quad$ Big FM was the first channel to play Kannada music and programs 24/7 when the competitor channels were playing only one hour of regional language programs.

$+\quad$ Local language film star Upendra was the brand ambassador for Reliance products/services for the first time in Indian film history.

+ Reliance was the first telecom company to use a regional star Sudeep as Brand Ambassador and then continued with Kannada film star Ganesh.

$+\quad$ It was the first to launch Kannada Radio awards.

All this explanation and convincing seemed to have made KFCC members relent a little. They asked to be given five minutes to come to a decision on 
Mr.Prashanth's proposal. Mr. Prashanth stepped out of the meeting hall and made use of the opportunity to make calls to film industry insiders to convince KFCC to call off the Bundh. He had also gathered from the cross talks among members that, KFCC was finding it difficult to mobilize all artists as most of them were away on shoots outside Bangalore. Also, he sensed some murmurs of opposition to the Bundh from some sections of the film fraternity, who would lose money if shootings were to be cancelled on $2^{\text {nd }}$ August. He realized, that if Reliance were to offer a face saving formula to KFCC, it would be glad to call off the bundh.

It was almost midnight when Mr. Prashanth was called back inside the meeting hall and president of KFCC announced the decision. He thanked $\mathrm{Mr}$ Prashanth for the proposal, but KFCC would not accept it. He said that the since the bundh was announced citing the hurt ego of Kannadigas, he would be answerable to millions of Kannadigas if the bundh was called off, and nothing less than closure of the radio station was acceptable to KFCC.

Mr Prashanth, at this point, said that he did not have the authority to agree for the closure of the station and that he needed to speak to Bombay for this.

\section{The Turning Point}

Mr Prashanth called Mr Tarun Kataria, only to be surprised to find Mr Satish Seth on the other end. Mr. Seth is Mr Kataria's boss. In fact all the top officials of Reliance ADAG were gathered at Mr. Amithabh Jhunjunwallah's birthday party.

After having got blanket permission from Bombay to agree to anything to avert the strike and the protest march, Mr Prashanth came back into the hall and dramatically announced the closure of the radio station. But, he said that it would be for one hour!

This prompted the KFCC to say, that if Reliance was willing to close down for one hour, then why not for one month or at least 15 days. Then Mr. Prashanth offered to close down for half a day. At this point, The haggling went on till it was finally decided that the radio station would be closed down for one day on $2^{\text {nd }}$ August, 2010 with Big FM Radio airing apologies every half hour from the subsequent day. The other demands that KFCC squeezed out from Reliance for having toned down to one day closure from one month closure included -

+ Suspension of the RJ for one month

+ A written apology

+ Apology to be published in all major newspapers

On its part KFCC agreed to call off the proposed bundh and protest march, withdraw its boycott of the music channel and remove the ban on artists working for and with Big FM Radio.

A press conference to announce the successful resolution of the conflict was held the next morning.

\section{Discussion Questions}

1. What according to you are the reasons for the initial negotiations to fail?

2. What factors contributed to the resolution of the conflict eventually?

3. Was the outcome of the conflict resolution a winwin one?

\section{Sources}

Personal interview by the authors with the mediator Mr Prashanth Sambargi

http://www.chitraloka.com/news/139-films-latestnews/2667-anti-industry-channel-927fm. html?5835f6087eac4ed250b8054e531d5 $91 \mathrm{c}=\mathrm{dfe} 695 \mathrm{febbc} 3 \mathrm{f} 124 \mathrm{e} 969087 \mathrm{a} 55150676$ (retrieved on 17/08/2010) http://www.chitratara.com/ s how contente.php? id = 2177 \& ptype $=$ News \& title $=$ KFI\%20BUNDH $\% 20 \mathrm{P}$ UT \% 20 OFF \% 20\% $96 \% 20$ BI G \% 2092.7\% 20FM\%20TAKES\%20PUNISHMENT

(Retrieved on17/08/2010)

http://www.hinduonnet.com/2010/08/02/stories/ 2010080256480500.htm (retrieved on 17/08/2010)

http://economictimes.indiatimes.com/articleshow/ 6067200.cms (retrieved on 18/08/2010)

http://chitraloka.com/kannada-chitraloka-latestnews/140/2662.html (retrieved on 18/08/2010)

http://www.hinduonnet.com/2010/08/02/stories/ 2010080256480500.html (retrieved on 18/08/2010) http://www.prokerala.com/news/articles/ a155871.html (retrieved on 18/08/2010) 